\title{
PERALIHAN HAK MILIK ATAS TANAH KARENA PEWARISAN TERHADAP TANAH GANGGAM BAUNTUAK
}

\author{
Wahyudi $^{1}$, Najmi ${ }^{2}$ \\ Program Magister Kenotariatan Fakultas Hukum Universitas Andalas \\ Jl. Pancasila No. 10 Padang Telp/Fax:+62-751-27404, email:aufaslank@gmail.com \\ Fakultas Hukum Universitas Andalas Jl. Pancasila No. 10 Padang \\ Telp/Fax: +62-751-27404, email: najmi30@ymail.com \\ Submitted : 03/08/2019 Reviewed 20/09/2019 Accepted:30/09/2019
}

\begin{abstract}
Ganggam bauntuak is a distribution method of land ownership to the kaum member. The rights holders of ganggam bauntuak is not only as users, but also as the owner in common ownership by kaum members. Land registration of ganggam bauntuakget a certificates of ownership, by enrolling ganggam bauntuak land will clarify the ownership status as communal indigenous land if registered in the name of the communal, however in the implementation ganggam bauntuak land more registered on behalf of individuals. The method used in this research is juridicalempirical.The result showed that the ganggam bauntuak on pusako tinggiin Bukittinggi citybegins with the kaum discussion to divide pusako tinggi management. After the kaum agreement, mamak kepala waris give ganggam bauntuak to each jurai.The inheritance of pusako tinggi that form as ganggam bauntuak continued by the heirs of the ganggam bauntuak rights holder according by line of mother descent jurai(Matrilineal). The registration process of ownership transfer on the ganggam bauntuak land because of hereditary doing under the provisions applicable laws, compatible with chapter 42 of PP no. 24 years 1997 about the land registration, and specifically stipulated in chapter 111 of PMNA/K-BPN number 3 years 1997.
\end{abstract}

Keywords: Inheritance; Land ownership; Ganggam bauntuak.

Abstrak:Ganggam bauntuak merupakan metode pembagian tanah milik kaum kepada anggota kaum. Pemegang hak ganggam bauntuak bukan hanya berstatus pemakai, akan tetapi juga sebagai pemilik dalam kepemilikan bersama oleh anggota kaum. Pendaftaran tanah ganggam bauntuak menghasilkan sertipikat hak milik, dengan mendaftarkan tanah ganggam bauntuak akan mempertegas status kepemilikannya sebagai tanah milik adat yang komunal selama didaftarkan atas nama 
kaum, akan tetapi dalam pelaksanaanya tanah ganggam bauntuak lebih banyak didaftarkan atas nama perorangan. Metode penelitian yang digunakan adalah yuridis empiris, yaitu dengan memperhatikan norma-norma hukum yang berlaku lalu membandingkannya dengan kenyataan atau fakta yang terjadi di lapangan. Hasil penelitian menunjukkan bahwa terjadinya ganggam bauntuak atas pusaka tinggi di Kota Bukittinggi diawali dengan musyawarah kaum untuk membagi pengelolaan pusaka tinggi. Setelah adanya kesepakatan kaum, mamak kepala waris memberikan ganggam bauntuak kepada masing-masing jurai. Pewarisan terhadap tanah pusaka tinggi yang sudah ganggam bauntuak adalah dilanjutkan pengelolaannya oleh ahli waris pemegang hak ganggam bauntuak yang sajurai menurut garis keturunan ibu (Matrilineal). Proses pendaftaran peralihan hak milik atas tanah ganggam bauntuak karena pewarisan dilakukan berdasarkan ketentuan hukum yang berlaku sesuai dengan Pasal 42 Peraturan Pemerintah No. 24 Tahun 1997 tentang Pendaftaran Tanah, dan secara khusus diatur dalam Pasal 111 PMNA/K-BPN Nomor 3 Tahun 1997.

Kata kunci: Pewarisan; Hak milik atas tanah; dan Ganggam bauntuak.

\section{PENDAHULUAN}

Hak atas tanah adalah hak yang memberikan wewenang kepada pemegang haknya untuk mempergunakan dan mengambil manfaat dari tanah yang dihakinya. Hak atas tanah terdiri dari tanah yang dimiliki oleh perorangan dan tanah yang dikuasai oleh masyarakat adat secara berkelompok. Hak dan wewenang masyarakat hukum adat untuk menguasai tanah secara berkelompok dalam wilayahnya dikenal dengan istilah hak ulayat.

Hak ulayat merupakan hak kolektif atau kewenanganyang dipunyai oleh masyarakat hukum adat terhadap tanah-tanah dalam wilayah mereka. Negara mengakui dan menghormati kesatuan-kesatuan masyarakat hukum adat beserta hak-hak tradisionalnya sepanjang masih hidup dan sesuai dengan perkembangan masyarakat dan prinsip Negara Kesatuan Republik Indonesia,hal ini dinyatakan dalam Undang-Undang Dasar 1945 (amandemen) Pasal 18 B ayat (2). Selanjutnya pada pasal 5 Undang-undang Nomor 5 tahun 1960 ten- tang Peraturan Dasar Pokok-Pokok Agraria atau lebih dikenal dengan Undang-Undang Pokok Agraria (untuk selanjutnya disebut UUPA), dinyatakan bahwa "Hukum agraria yang berlaku atas bumi, air, dan ruang angkasa adalah hukum adat", Berdasarkan pasal tersebut dapat disimpulkan bahwaUUPA menggunakan hukum adat sebagai pelengkap hukum positif yang tertulis. Hukum adat yang dimaksud tentunya hukum adat yang telah di-saneer(disaring) yang dihilangkan cacatcacatnya dan disempurnakan. ${ }^{1}$

Salah satu masyarakat hukum adat yang memiliki hubungan erat dengan ulayatnya adalah masyarakat adat Minangkabau. Menurut adat Minangkabau seluruh tanah dan hutan mulai dari pohon yang sebatang, batu yang sebutir sampai rumput yang sehelai, yang tingginya sampai ke angkasa dan kedalamannya sampai ke perut bumi adalah

1 Sajuti Thalib. 1985. Hubungan Tanah Adat dengan Hukum Agraria. Jakarta: Bina Aksara, hlm 20-21 
ulayat. $^{2}$ Tanah ulayat di Minangkabau dapat dibagi dalam beberapa jenis, yaitu:

a. Tanah ulayat rajo, yaitu tanah yang penguasannya ada pada penghulu dan letaknya jauh dari kampung.

b. Tanah ulayat nagari, yaitu tanah yang letaknya dekat dari kampung yang dikuasai oleh penghulu-penghulu dalam nagari.

c. Tanah ulayat suku, ialah tanah yang dipunyai secara bersama oleh seluruh anggota suku yang diwarisi secara turun-temurun dalam keadaan utuh di bawah penguasaan penghulu suku.

d. Tanah ulayat kaum, yaitu tanah yang dimiliki secara bersama dalam garis keturunan matrilineal yang diwarisi secara turun-temurun dalam keadaan utuh yang tidak terbagi-bagi. Tanah ulayat kaum lebih dikenal dengan pusaka tinggi. ${ }^{3}$

Berdasarkan jenis tanah ulayat yang disebutkan diatas, maka hanya ulayat rajo dan ulayat nagari saja yang cocok dengan pengertian hak ulayat secara yuridis menurut hukum agraria nasional (UUPA) sebagai hak menguasai masyarakat hukum adatterhadap wilayahnya, sedangkan ulayat suku,ulayat kaum, dan tanah ganggam bauntuak yang tercakup didalam ulayat kaum lebih tepat dikategorikan sebagai tanah milik adat yang komunal. ${ }^{4}$

Tanah ulayat kaum atau pusaka tinggi merupakan harta milik bersama kaum yang diwarisi secara turun-temurun. Terhadap

2 Nurdin Yakub. 1989. Minangkabau Tanah Pusaka, Tambo Minangkabau, Buku Kedua, Cetakan Pertam. Bukittinggi: Pustaka Indonesia, hlm 55.

3 Kurnia Warman. 2010. Hukum Agraria Dalam Masyarakat Majemuk, Dinamika Interaksi Hukum Adat dan Hukum Negara di Sumatera Barat. Jakarta: Van Vollenhoven Institute Leiden University, KITLV \& HuMa-Jakarta, hlm 120.

$4 \quad$ Ibid, hlm 11. harta pusaka tinggi berlaku ketentuan Ganggam nan bauntuak, Hak bapunyo, Miliek bamasiang. Pusaka tinggi yang belum dibagi sesuai prinsip ganggam nan bauntuak, hak bapunyo, miliek bamasiang dikelola secara bergiliran diantara kelompok keluarga yang sajurai maupun samandeh (seibu). ${ }^{5}$

Pengertian ganggam bauntuak dapat dilihat pada Peraturan Daerah Provinsi Sumatera Barat Nomor 6 Tahun 2008 tentang Tanah Ulayat dan Pemanfaatannya, dalam Pasal 1 angka 18 disebutkan bahwa:"Ganggam Bauntuak adalah peruntukan tanah ulayat kaum oleh mamak kepala waris $^{6}$ kepada anggota kaumnya secara hirarkis menurut garis keturunan ibu". Menurut Bachtiar Abna "Hak ganggam bauntuak sebagai hak perseorangan yang diletakkan diatas hak persekutuan didalam hukum tanah adat Minangkabau. Hak persekutuan tetap ada walaupun bidang tanah tertentu dari wilayah persekutuan telah diserahkan dengan hak individu kepada warga persekutuan, inilah yang dikenal dengan prinsip Kabau tagak kubangan tingga,yang dapat dibawa hanya hasilnya saja sedangkan tanahnya kembali menjadi tanah ulayat (milik kaum)". 7

Pendaftaran tanah ulayat kaum yang mencakup tanah ganggam bauntuak di-

5 Amir. M.S. 2011. Pewarisan Harato Pusako Tinggi dan Pencaharian Minangkabau, cetakan keempat. Jakarta: Citra Harta Prima, hlm. 28-30.

6 Mamak kepala waris adalah nama jabatan dalam suatu kaum yang bertugas memimpin seluruh anggota kaum dan mengurus, mengatur, mengawasi serta bertanggung jawab atas hal-hal terkait pusaka kaum.

7 Bachtiar Abna. b. 2007. Pengelolaan Tanah Negara dan Tanah Ulayat. Padang: Lembaga Kerapatan Adat Alam Minangkabau (LKAAM) Sumatera Barat, http://repo.unand.ac.id/2619/1/ Tanah_Negara_dan_Tanah_Ulayat.doc, (diakses tanggal 4 Mei 2019), hlm. 6 
dalamnya, juga dinyatakan dalam Peraturan Daerah Provinsi Sumatera Barat Nomor 6 tahun 2008 pada Pasal 8 huruf(c) menyatakan: "Terhadap tanah ulayat kaum dapat didaftarkan, sebagai subjek pemegang hak adalah anggota kaum dan mamak kepala waris dengan status hak milik". Ganggam bauntuak didaftarkan menjadi hak milik disebabkan karena keberadaan isi hak tersebut merupakan hak milik adat yang komunal. Pemegang hak ganggam bauntuak bukan hanya berstatus pemakai, akan tetapi juga sebagai pemilik langsung dimana tanah tersebut berada. ${ }^{8}$

Pasal 20 ayat (1) UUPA menyatakan bahwa hak milik adalah hak turun temurun, terkuat dan terpenuh yang dapat dipunyai orang atas tanah, selanjutnya pada ayat (2) menyatakan bahwa hak milik atas tanah dapat beralih maupun dialihkan kepada pihak lain. Beralih terjadi karena adanya peristiwa hukum yaitu meninggal dunianya pemilik tanah dan terjadinya Pewarisan, sedangkan dialihkan adalah dengan melakukan perbuatan hukum seperti jual beli, tukar menukar, dan hibah.

Peralihan hak terhadap tanah milik adat yang komunal seperti harta pusaka telah diatur dalam hukum adat Minangkabau. Peralihan harta pusaka terjadi karena dipusakai secara turun-temurun berdasarkan sistem pewarisan Matrilineal. Tanah ganggam bauntuak yang didaftarkan menjadi hak milik atas nama kaum (atas nama mamak kepala waris) akan mempertegas status kepemilikannya sebagai tanah milik adat yang komunal. Selain didaftarkan atas nama kaum, pendaftaran tanah ganggam bauntuak juga ditemukan didaft-

8 Kurnia Warman. a. 2006. Ganggam Bauntuak Menjadi Hak Milik: Penyimpangan Konversi Hak Atas Tanah di Sumatra Barat. Padang: Andalas University Press, hlm 153. arkan atas nama perorangan anggota kaum. Setelah ganggam bauntuak menjadi hak milik baik atas nama kaum ataupun perorangan anggota kaum, bagaimanakah pewarisan tanah tersebut dalam pelaksanaanya.

Berdasarkan gambaran permasalahan yang telah dikemukakan diatas, maka identifikasi masalah yang dibahas dalam penelitian ini adalah sebagai berikut:

1. Bagaimanakah proses terjadinya ganggam bauntuak atas pusaka tinggi di Kota Bukittinggi?

2. Bagaimanakah pewarisan terhadap tanah pusaka tinggi yang sudah ganggam bauntuak di Kota Bukittinggi?

3. Bagaimanakah proses pendaftaran peralihan hak milik atas tanah karena Pewarisan terhadap tanah ganggam bauntuak diKota Bukittinggi?

\section{METODE}

Penelitian pada dasarnya merupakan "suatu upaya pencarian" dan bukan hanya sekedar mengamati dengan teliti terhadap sesuatu objek yang mudah terpegang ditangan. Penelitian merupakan terjemahan dari bahasa Inggris yaitu research, yang berasal dari kata re (kembali) dan to search (mencari). Dengan demikian secara logawiyah berarti mencari kembali. ${ }^{9}$ Metode penelitian adalah suatu cara yang mengandung teknik, yang berfungsi sebagai alat dalam suatu penelitian. Suatu metode penelitian diharapkan mampu untuk menemukan, merumuskan, menganalisis, dan mampu memecahkan masalah-masalah dalam suatu penelitian. Agar data diperoleh lengkap, relevan, akurat, dan dapat diandalkan, maka digunakan metode penelitian sebagai berikut:

1. Metode pendekatan dan Sifat Penelitian Metode pendekatan yang digunakan

9 Bambang Sunggono. 1997. Metodologi Penelitian Hukum. Jakarta: PT Grafindo Persada, hlm. 27. 
dalam penelitian ini adalah Yuridis Empiris (Socio legal research), yaitu penelitian yang dilakukan dengan memperhatikan norma-norma hukum yang berlaku, lalu membandingkannya dengan kenyataan atau fakta-fakta yang terjadi di lapangan. Penelitian ini bersifat Deskriptif, yaitu suatu metode yang menggambarkan atau menguraikan mengenai fakta-fakta, sifat-sifat serta hubungan antar fenomena yang diselidiki.

2. Sumber dan Jenis data

Sumber data pada penelitian Yuridis Empiris bersumber dari studi pustaka (library research) dan penelitian lapangan (field research). Studi pustaka dilakukan dengan mempelajari literatur, Peraturan dan buku-buku sebagai bahan hukum yang berhubungan dengan permasalahan dengan melakukan riset pada perpustakaan. Penelitian lapangan dilakukan untuk mengetahui penerapan norma hukum berdasarkan kenyataan atau faktafakta hukum yang terjadi di lapangan.

Jenis data terdiri dari data primer dan data sekunder. Data primer adalah data yang diperoleh secara langsung dari penelitian lapangan, melalui wawancara atau interview yang dilakukan dengan pihak-pihak yang terkait dengan penelitian. Wawancara atau interview dilakukan dengan Pejabat Kantor Pertanahan Kota Bukittinggi berkaitan dengan pendaftaran peralihan hak milik atas tanah dan wawancara dengan Pemuka adat Kerapatan Adat Nagari di Kota Bukittinggi berkaitan dengan Harta Pusaka dan ganggam bauntuak.

Data sekunder yaitu data yang diperoleh dari penelitian kepustakaan, berupa bahan hukum yang terdiri dari: a. Bahan Hukum Primer adalah peraturan hukum yang mengikat, yang terdiri dari peraturan prundangundangan, Peraturan Hukum Adat Minangkabau, dan Yurisprudensi berkaitan dengan Harta Pusaka.

b. Bahan Hukum Sekunder adalah bahan hukum yang memberikan petunjuk maupun penjelasan terhadap bahan hukum primer serta implementasinya seperti artikel ilmiah, jurnal ilmiah, buku yang berkaitan dengan permasalahan yang diteliti, makalah ilmiah, Tesis, dan Disertasi.

c. Bahan Hukum Tersier adalah bahan hukum yang memberi penjelasan terhadap bahan hukum primer dan bahan hukum sekunder, seperti kamus hukum. ${ }^{10}$

3. Metode Pengumpulan Data

Pengumpulan data merupakan hal yang sangat erat hubungannya dengan sumber data, karena melalui pengumpulan data ini akan diperoleh data yang diperlukan untuk selanjutnya dianalisa. Metode pengumpulan data yang digunakan dalam penelitian ini adalah:

a. Studi dokumen adalah teknik pengumpulan data dengan mencari dan mempelajari buku-buku dan dokumen-dokumenyang berkaitan dengan permasalahan yang akan diteliti dengan melakukan riset pada perpustakaan.

b. Wawancara atau interview adalah teknik pengumpulan data yang dilakukan secara lisan guna memperoleh informasi dari responden yang erat kaitannya dengan perma-

10 Zainuddin Ali. 2009. Metode Penelitian Hukum. Jakarta: Sinar Grafika, hlm 106. 
salahan yang diteliti dilapangan.

4. Pengolahan dan analisis data

Data yang telah diperoleh kemudian diolah dengan melakukan editing, kegiatan editing dilakukan untuk memeriksa dan mengoreksi hasil penelitian sehingga tersusun secara sistematis dan didapatkan suatu kesimpulan. Selanjutnya dilakukan kodifikasi (Coding) data sesuai kategori masing-masing agar dapat disajikan secara sistematis. Dalam menganalisis data dilakukan analisis kualitatif, analisis kualitatif adalah pernyataan-pernyataan berupa uraian kalimat yang logis dan menilainya berdasarkan aturan perundangundangan, teori para ahli dan logika agar dapat ditarik kesimpulan yang tepat.

\section{ANALISIS DAN PEMBAHASAN}

\section{Proses Terjadinya Ganggam Bauntuak} Atas PusakaTinggi di Kota Bukittinggi

Terjadinya ganggam bauntuak dipengaruhi oleh perkembangan suatu kaum, apabila kaum telah berkembang dan tidak dimungkinkan lagi dilakukan pengelolaan pusaka tinggi secara bergiliran, maka tanah kaum dibagi secara ganggam bauntuak. Selain itu, ganggam bauntuak dapat terjadi apabila tanah kaum akan didaftarkan atas nama anggota kaum dalam kelompok keluarga sajurai (kelompok keluarga se-nenek) ataupun $s a$ mandeh (seibu).

Pembagian tanah milik kaum pada umumnya dilakukan tanpa bukti tertulis, dengan kata lain lahirnya ganggam bauntuak hanya berdasarkan kaum meeting dan bukanlah berdasarkan perjanjian atau pemberian, bahkan lazimnya hasil musyawarah itu pun tidak dicatat, sehingga ganggam bauntuak hanya dibuktikan dengan penguasaan yang nyata terhadap tanahnya. ${ }^{11}$ Kedudukan ganggam

11 Kurnia Warman. a, Op.cit., hlm 91-92. bauntuak terhadap harta pusaka tinggi adalah berupa hak pakai untuk mengelola dan mengambil manfaat. Setiap pengaturan dan penggunaan hasil pusaka tinggi diatur secara adil oleh penghulu suku bersama dengan mamak kepala waris. ${ }^{12}$

Mamak kepala waris sebagai pemimpin dalam kaum mempunyai peran yang sangat penting, setiap tindakan yang berhubungan dengan harta pusaka baik didalam maupun diluar kaum dilaksanakan oleh mamak kepala waris berdasarkan mufakat seluruh anggota kaum. ${ }^{13}$ Mamak kepala waris mempunyai kewenangan untuk mengatur dan mengawasi pengelolaan harta pusaka tinggi. Mamak kepala waris yang memberikan hak ganggam bauntuak dan juga berhak menarik kembali ganggam bauntuak dengan kesepakatan seluruh anggota kaum. ${ }^{14}$

Langkah-langkah yang diambil oleh $m a-$ mak kepala waris sebagai pemimpin kaum dalam melaksanakan ganggam bauntuak adalah:

1. Mengumpulkan seluruh anggota kaum untuk melakukan rapat kaum.

2. Rapat atau musyawarah kaum dilakukan untuk membagi pengelolaan harta pusaka tinggi kepada masing-masing kelompok jurai/paruik berdasarkan alua jo patuik atau secara adil.

3. Keputusan untuk membagi pengelolaan baru boleh dijalankan apabila diperoleh

12 Wahyudi. 2016. Kedudukan Ganggam Bauntuak Dalam Harta Pusaka Tinggi Sebagai Tanah Ulayat Kaum di Minangkabau. Skripsi. Bukittinggi: FH UMSB, hlm 60.

13 Idrus Hakimy Dt. Rajo Penghulu. 1978. Rangkaian Mustika Adat Basandi Syarak Di Minangkabau. Bandung: CV Rosda., hlm 51.

14 Chairul Anwar. 1997. Hukum Adat Indonesia, Meninjau Hukum Adat Minangkabau. Jakarta: PT Rineka Cipta, hlm. 92-94. 
kata saiyo sapakat (seia semufakat) seluruh anggota kaum.

4. Ganggam Bauntuak umumnya diberikan atas nama nenek atau perempuan tertua pada masing-masing jurai/paruik.

5. Apabila tanah ganggam bauntuak akan didaftarkan, maka kaum membuat surat kesepakatan pembagian tanah kaum atau pusaka tinggi untuk masing-masing $j u$ rai/paruik..$^{15}$

UUPA menegaskan konversi ganggam bauntuak menjadi hak pakai hal ini dinyatakan pada Pasal VI Ketentuan Konversi, namun dalam pelaksanaannya ganggam bauntuak dikonversi menjadi hak milik.Konversi ganggam bauntuak berpedoman pada ketentuan Peraturan menteri Pertanian dan Agraria (PMPA) Nomor 2 Tahun 1962 tentang Penegasan Konversi Bekas Hak Indonesia Atas Tanah. Mekanisme konversi tanah ganggam bauntuak tidak berdiri sendiri melainkan menyatu dalam mekanisme konversi tanah milik kaum. ${ }^{16}$ Menurut Kurnia Warman, Ganggam bauntuak didaftarkan menjadi hak milik disebabkan karena keberadaan isi hak tersebut merupakan hak milik adat yang komunal. Pemegang hak ganggam bauntuak bukan hanya berstatus pemakai, akan tetapi juga sebagai pemilik langsung dimana tanah tersebut berada. ${ }^{17}$ Pendaftaran tanah ganggam bauntuak menjadi hak milik tidak akan menghapus statusnya sebagai pusaka tinggi milik kaum, dengan pensertipikatan justru semakin mempertegas status kepemilikan, le-

15 Berdasarkan wawancara dengan Syafril. Dt. Tan Magedan: Bidang Sako joPusako Kerapatan Adat Nagari Jorong Mandiagin, (tanggal 23 Mei 2019).

16 Kurnia Warman. 1999. "Konversi Hak Atas Tanah Ganggam bauntuak Menurut UUPA Di Sumatera Barat". Jurnal: Sosiohumanika, Yogyakarta, 12(2): 239-240.

17 Kurnia Warman. a, Op.cit., hlm 153. tak, serta luas dan batas-batas tanah ganggam bauntuak. $^{18}$

Berdasarkan penelitian yang penulis lakukan di Kota Bukittinggi, pada saat sekarang pendaftaran tanah ganggam bauntuak lebih banyak didaftarkan atas nama perorangan anggota kaum dibandingkan atas nama kaum (atas nama mamak kepala waris). Individualisasi harta pusaka tinggikaum bukanlah menjadi hal baru karena telah diungkapkan oleh penelitian-penelitian terdahulu. Kecenderungan untuk membagi tanah kaum dapat dilihat pada tanah ganggam bauntuak yang akan didaftarkan. Ganggam bauntuak dapat didaftarkan atas nama mamak kepala waris ataupun atas nama anggota kaum sebagai hak milik bersama pemegang ganggam bauntuak. Terhadap tanah kaum, baik didaftarkan secara keseluruhan atas nama kaum, dibagi-bagi secara ganggam bauntuak menjadi hak milik kelompok keluarga sajurai/paruik, bahkan dibagi menjadi milik pribadi sekalipun, hal itu diserahkan kepada kesepakatan kaum yang bersangkutan.

Harta pusaka tinggi milik kaum yang telah dibagi akan menjadi pusaka rendah. Jika harta pusaka rendah tetap utuh tidak dibagibagi dan diwariskan lagi, maka dengan sendirinya harta pusaka rendah tersebut akan berubah menjadi harta susuk. Harta Susuk merupakan harta yang disisipkan ke dalam harta pusaka tinggi. Harta susuk inilah yang kemudian menjadikan harta pusaka tinggi semakin bertambah. ${ }^{19}$ Perubahan kedudukan harta pusaka tinggi dan harta pusaka rendah telah diungkapkan oleh M. Nasroen, bahwa

18 Ibid., hlm 73.

19 Suardi Mahyudin. 2009. Dinamika Sistem Hukum Adat Minangkabau dalam Yurisprudensi Mahkamah Agung. Jakarta: PT.Candi Cipta Paramuda, hlm 97. 
antara hak komunal (milik kaum) dengan hak perorangan di Minangkabau mengikuti perputaran yang terus menerus. Harta pusaka tinggi bisa beralih menjadi pusaka rendah, sebaliknya harta pusaka rendahpun secara perlahan-lahan menjadi pusaka tinggi. ${ }^{20}$

\section{PewarisanTerhadap TanahPusaka Tinggi Yang Sudah Ganggam Bauntuak Di Kota Bukittinggi}

Pewarisan adalah proses berpindahnya harta kekayaan dari seseorang yang meninggal dunia kepada para ahli warisnya. Pewarisan hak atas tanah adalah berpindahnya hak atas tanah dari pemegang hak sebagai pewaris kepada pihak lain sebagai ahli waris karena pemegang haknya meninggal dunia. Unsur pewarisan terdiri dari pewaris, ahli waris, dan harta warisan.

Pewarisan menurut hukum adat Minangkabau adalah perpindahan harta kekayaan suatu generasi kepada generasi berikutnya. Secara garis besar harta benda waris dalam masyarakat Minangkabau dapat dibagi menjadi dua golongan, yaitu harta pusaka dan harta pencaharian. Pada dasarnya telah terjadi kesepakatan baik secara teori maupun dalam praktek oleh masyarakat Minangkabau, bahwa harta pencaharian diwariskan kepada anak dan isteri menurut faraidh hukum Islam, sedangkan terhadap harta pusaka berlaku hukum Adat Minangkabau. ${ }^{21}$

Ketentuan tentang harta pusaka diungkapkan dengan "Warih dijawek, pusako ditolong”. Ungkapan warih dijawek artinya waris diisi ditentukan siapa ahli warisnya, pusako ditolong diartikan bahwa harta pusaka itu harus terpelihara dengan baik, jangan sampai berpindah kepada pihak lain atau terjual,karena

20 Kurnia Warman. a, Op.cit., hlm 145.

21 Amir M.S, Op.cit., hlm 22-23. harta pusaka merupakan dana cadangan kaum. ${ }^{22}$ Ketentuan adat Minangkabau terkait pewarisan harta pusaka diungkapkan dengan "Biriek-biriek tabang ka sasak, dari sasak turun ka halaman, dari niniek turun ka mamak, dari mamak turun ka kamanakan, Pusako baitu juo". ${ }^{23}$ Pemindahan kekuasaan harta pusaka dari mamak kepada kemenakan dalam istilah adat disebut dengan pusako basalin.

Menurut Chairul Anwar, jika dihadapkan pada harta pusaka maka sudah jelas bahwa ahli warisnya adalah anggota-anggota keluarga dari garis keturunan ibu. Apabila seorang ibu meninggal, maka yang pertama menjadi ahli warisnya adalah anak-anaknya, kemudian cucu-cucunya, serta akhirnya keturunan selanjutnya dari mereka. Keturunan-keturunan tersebut dikenal dengan istilah warih nan dakek (ahli waris yang dekat). Apabila warih nan dakek sudah tidak ada lagi, maka sebagai ahli warisnya dicari warih nan jauah. Warih nan jauah adalah semua anggota keluarga yang sedarah yang dilihat dari garis keturunan ibu, apabila tidak ada maka warih nan jauah adalah anggota-anggota dari lingkungan sedarah yang berasal dari moyang yang sama. $^{24}$

Menurut adat Minangkabau hubungan antara yang mewariskan dengan penerima warisan dapat dibedakan atas dua bagian, yaitu warih nasab dan warih sabab.

1. Warih Nasab (waris bertali darah) adalah pewarisan karena adanya pertalian darah. Harta pusaka diwarisi secara turun temurun (dipusakai) berdasarkan garis

22 Idrus Hakimy Dt. Rajo Penghulu,Op.cit., hlm 185.

23 Nurullah Dt. Perpatih Nan Tuo.1999. Tanah Ulayat Menurut Ajaran Adat Minangkabau, Yayasan Sako Batuah LKAAM Sumatera Barat. Padang: PT.Singgalang Press, hlm 7-8.

24 Chairul Anwar, Op.cit., 89-90. 
keturunan ibu. Apabila ahli waris nasab tidak ada lagi maka ahli waris batali adat berhak sebagai ahli waris. ${ }^{25}$

2. Warih Sabab terjadi karena suatu sebab yang hanya berkaitan dengan harta pusaka, waris sabab ini dibedakan atas tiga bagian, yaitu:

a. Warih Batali Adat (waris bertali adat) seperti hubungan sesuku, apabila suatu kaum punah dalam arti tidak ada lagi keturunan menurut garis keturunan ibu, maka harta pusaka dari kaum yang punah tersebut dapat jatuh kepada kaum yang sesuku dengannya di kampung tersebut.

b. Warih Batali Buek (waris bertali buat) maksudnya waris berdasarkan peraturan yang dibuat sepanjang dibenarkan oleh adat.

c. Warih Batali Budi (waris bertali budi)terjadi karena kebaikan budi dan tingkah laku seseorang sehingga dianggap seperti anak kemenakan, kemudian dengan mufakat kaum dia diberi hak atas harta pusaka. ${ }^{26}$

Pewarisan harta pusaka tinggi berkaitan erat dengan sistem kekerabatan matrilineal yang dianut masyarakat Minangkabau. Pewarisan harta pusaka tinggi bukan dalam arti dibagi-bagi kepemilikannya,akan tetapi dilanjutkan pengelolaannya oleh para ahli waris. Tanah pusaka tinggi yang sudah ganggam bauntuakakan diwariskan kepada ahli waris penerima ganggam bauntuak dalam keturunan yang sajurai.

Ganggam bauntuak yang telah didaftarkan menjadi hak milik baik atas nama kaum maupun atas nama anggota kaum tetap mengacu pada sistem pewarisan Matrilineal. Apa-

25 Suardi Mahyuddin, Op.cit., hlm 263-264.

26 Ibid. bila tanah ganggam bauntuak didaftarkan atas nama anggota kaum yang perempuan, maka sudah jelas diwariskan kepada anak-anaknya. Jika tanah tersebut didaftarkan atas nama laki-laki selaku mamak kepala waris sebagai pemimpin kaum, maka akan diwariskan kepada kemenakannya. Selanjutnya kaum akan mengangkat mamak kepala waris yang baru untuk menggantikan mamak kepala waris yang telah meninggal dunia.

\section{Proses Pendaftaran Peralihan Hak Milik Atas Tanah Karena Pewarisan Terhadap Tanah Ganggam Bauntuak Di Kota Bukit- tinggi}

Peralihan hak milik atas tanah karena pewarisan wajib didaftarkan oleh ahli warisnya, mengenai siapa yang berhak menjadi ahli waris diatur dalam hukum adat yang berlaku bagi pewaris. Pendaftaran peralihan hak karena pewarisan diwajibkan dalam rangka memberikan perlindungan hukum kepada para ahli waris dan sebagai pembuktian yang kuat mengenai sahnya peralihan hak milik tersebut, hal ini dinyatakan pada Pasal 23 Undang-Undang Pokok Agraria Nomor 5 Tahun 1960.

Pelaksanaan pendaftaran tanah diatur dalam Pasal 11 sampai dengan Pasal 56 Peraturan Pemerintah (PP) Nomor 24 Tahun 1997 tentang Pendaftaran Tanah, Pelaksanaan pendaftaran tanah meliputi:

1. Kegiatan pendaftaran tanah untuk pertama kali, yaitu dengan melakukan permohonan hak baru (sertipikat) atas tanah yang belum terdaftar.

2. Kegiatan pemeliharaan data pendaftaran tanah, yaitu melakukan pendaftaran peralihan hak (balik nama) untuk tanah yang sudah terdaftar (bersertipikat).

Pemeliharaan data pendaftaran tanah berupa 
Peralihan hak karena Pewarisan disebutkan pada pada Pasal 42 ayat (1) PP Nomor 24 Tahun 1997, Pasal ini menyatakan bahwa:

(1) Untuk pendaftaran peralihan hak karena pewarisan mengenai bidang tanah yang sudah didaftar, ahli waris wajib menyerahkan kepada Kantor Pertanahan berupa: Sertipikat, surat kematian orang yang namanya dicatat sebagai pemegang hak, dan surat tanda bukti sebagai ahli waris.

Pendaftaran Peralihan hak berupa Pemeliharaan data pendaftaran tanah diatur secara khusus padaPeraturan Menteri Negara Agraria/Kepala Badan Pertanahan Nasional (PMNA/KBPN) Nomor 3 Tahun 1997 tentang Ketentuan Pelaksana PP Nomor 24 Tahun 1997 Tentang Pendaftaran Tanah. Pemeliharaan data pendaftaran tanah terkait perubahan data yuridis objek pendaftaran tanah yang telah terdaftar berupa Peralihan hak karena Pewarisan disebutkan pada Pasal 94 ayat (2) Peraturan Menteri Negara Agraria/ Kepala BPN Nomor 3 Tahun 1997.

Proses pendaftaran peralihan hak milik atas tanah karena pewarisan terhadap tanah ganggam bauntuak terdiri dari:

1. Pengurusan surat keterangan kematian dan surat keterangan ahli waris di kelurahan sebagai dasar Pewarisan.

Lurah mempunyai peran penting berkaitan dengan proses peralihan hak atas tanah, disamping sebagai kepala wilayah Lurah dianggap sebagai seorang yang mengetahui kondisi dan status tanah. Persyaratan untuk melakukan peralihan hak milik karena pewarisan yang diserahkan ke Kantor Pertanahan (BPN) adalah Surat Keterangan Kematian yang dikeluarkan oleh Lurah setempat dan dikuatkan oleh Camat.Selain surat keterangan kematian, surat keterangan waris juga menjadi persyaratan yang diminta oleh Kantor Pertanahan untuk melakukan balik nama atas harta peninggalan dari pewaris kepada nama para ahli waris. ${ }^{27}$

2. Mengajukan permohonan Peralihan hak karena Pewarisan di kantor Pertanahan dengan melampirkan berkas-berkas yang diperlukan.

Prosedur Permohonan Peralihan Hak Karena Pewarisan diatur dalam Pasal 111 PMNA/ KBPN Nomor 3 Tahun 1997, Pasal 111 Ayat (1) menyebutkan bahwa Permohonan pendaftaran peralihan hak atas tanah atau Hak Milik Atas Satuan Rumah Susun diajukan oleh ahli waris atau kuasanya dengan melampirkan Sertipikat hak atas tanah, Surat kematian atas nama pemegang hak yang tercantum dalam sertipikat, dan Surat tanda bukti sebagai ahli waris.

3. Setelah berkas diserahkan di Kantor Pertanahan, maka akan ada tanda bukti penerimaan yang akan diserahkan kepada pemohon.

4. Selanjutnya Kantor pertanahan akan memproses dengan melakukan pencatatan peralihan hak dalam buku tanah, sertipikat dan daftar lainnya (melakukan balik nama kepada nama ahli waris).

Sebagaimana telah disebutkan pada pembahasan sebelumnya, tanah ganggam bauntuak dapat didaftarkan atas nama mamak kepala waris ataupun atas nama anggota kaum sebagai hak milik bersama. Berdasarkan penelitian yang dilakukan yang terjadi di Kota Bukit tinggi tanah kaum yang dibagi

27 Mhd Dwi Simon. 2017. Peralihan Hak Milik Atas Tanah Kaum Berdasarkan Pewarisan di Kota Payakumbuh. Tesis. Padang: Fakultas Hukum Universitas Andalas, hlm 95. 
secara ganggam bauntuak didaftarkan atas nama perorangan anggota kaum. Hal ini sejalan dengan penelitian Desi Sandra yang mengungkapkan bahwa pendaftaran tanah kaum yang dilakukan di Kota Bukittinggi, lebih banyak didaftarkan ke atas nama perorangan dari pada atas nama kaum. ${ }^{28}$

Berdasarkan penelitian yang penulis lakukan di Kantor Pertanahan Kota Bukittinggi. Syahrul ${ }^{29}$ menyatakan untuk melakukan permohonan peralihan hak milik atas tanah karena pewarisan (balik nama sertipikat) yang berasal dari tanah ganggam bauntuak, prosedurnya sama dengan peralihan hak milik karena pewarisan pada umumnya. Pemohon melengkapi berkas-berkas yang diperlukan dengan melampirkan sertipikat, surat keterangan kematian, surat keterangan ahli waris, ditambah dengan melampirkan ranji (silsilah) keturunan. Selanjutnya Syahrul mengungkapkan bahwa tanah kaum yang telah didaftarkan atas nama anggota kaum merupakan hak milik bersama pemegang ganggam bauntuak. ${ }^{30}$ Untuk melakukan balik nama sertipikat dapat dilakukan keatas nama anggota kaum yang perempuan (keturunan dari penerima ganggam bauntuak yang sajurai).

Menurut penulis, ganggam bauntuak yang dikategorikan sebagai tanah milik adat sudah tepat dikonversi menjadi hak milik. Ganggam bauntuak dikonversi menjadi hak

28 Desi Sandra. 2015. Pendaftaran Tanah Ulayat Kaum Untuk Kepastian Hukum Hak Atas Tanah di Kota Bukittinggi. Tesis. Padang:Fakultas Hukum, Universitas Andalas, hlm 97-98.

29 Sub Seksi Pemeliharaan Data Hak Tanah dan Pembinaan PPAT. Kantor Pertanahan Kota Bukittinggi

30 Berdasarkan wawancara dengan Syahrul. Sub Seksi Pemeliharaan Data Hak Tanah dan Pembinaan PPAT, Kantor Pertanahan Kota Bukittinggi, (tanggal 2 Mei 2019). milik dikarenakan pemegang hak ganggam bauntuak bukan hanya berstatus pemakai, akan tetapi juga sebagai pemilik dalam kepemilikan bersama oleh anggota kaum. Pasal 20 ayat (1) UUPA menyatakan bahwa "hak milik adalah hak turun temurun, terkuat dan terpenuh yang dapat dipunyai orang atas tanah", demikian juga dengan tanah kaum dan ganggam bauntuak yang bersifat turun temurun sehingga dapat diwariskan kepada keturunannya tanpa batas waktu dan batas generasi. Selanjutnya pada Pasal 22 ayat (1) UUPA menyatakan bahwa "terjadinya hak milik menurut hukum adat", dan tanah kaum yang ada di Minangkabau dikategorikan sebagai tanah milik adat yang komunal.

Hak milik hasil konversi ganggam bauntuak tetap menjadi milik kaum apabila didaftarkan atas nama mamak kepala waris selaku pemimpin kaum. Menipisnya hak komunal terlihat dari pendaftaran tanah ganggam bauntuak menjadi milik anggota kaum. Apabila didaftarkan atas nama anggota kaum, maka tanah tersebut menjadi hak milik bersama dalam kelompok keluarga(jurai)pemegang ganggam bauntuak.

Timbulnya penguatan hak perorangan atas pusaka tinggi kaum disebabkan karena semakin bertambahnya jumlah masyarakat hukum adat, sehingga kebutuhan akan tanah bertambah. Faktor penyebab lainnya adalah anggota kaum menginginkan kepastian akan haknya, oleh karena itu banyak tanah kaum yang dibagi dan didaftarkan atas nama salah seorang anggota kaum. Kecenderungan untuk membagi tanah kaum dengan mendaftarkan atas nama anggota kaum inilah yang menjadi celah atau cara untuk membagi-bagi tanah kaum dan berpotensi akan dibagi lagi menjadi hak milik masing-masing anggota kaum.

Implikasi hukum sertifikasi tanah gang- 
gam bauntuak setelah menjadi hak milik perorangan, menyalahi prinsip hukum adat Minangkabau dalam kepemilikan tanah ganggam bauntuak secara komunal.Hal ini disebabkan karena sertifikasi ganggam bauntuak dalam hukum agraria nasional memberi peluang kepada masyarakat untuk mendaftarkan atas nama perorangan, sehingga melemahkan nilai dan eksistensi hukum adat Minangkabau yang mengatur ganggam bauntuak tetap dimiliki secara komunal.

\section{PENUTUP}

\section{Kesimpulan}

1. Proses terjadinya ganggam bauntuak atas pusaka tinggi diawali dengan musyawarah kaum untuk membagi pengelolaan tanah kaum (pusaka tinggi). Ganggam bauntuak juga dapat terjadi apabila tanah kaum akan didaftarkan atas nama anggota kaum dalam kelompok keluarga sajurai maupun samandeh. Setelah adanya kesepakatan kaum, mamak kepala waris memberikan ganggam bauntuak kepada kepada masing-masing jurai ataupun samandeh.

2. Pewarisan harta pusaka tinggi bukan dalam arti dibagi-bagi kepemilikannya, akan tetapi dilanjutkan pengelolaannya oleh ahli waris secara turun-temurun menurut garis keturunan ibu, namun dalam pelaksanaannya pusaka tinggi dibagi-bagi dan didaftarkan atas nama perorangan anggota kaum. Tanah pusaka tinggi yang sudah ganggam bauntuak akan diwariskan kepada ahli waris penerima ganggam bauntuak dalam keturunan yang sajurai.

3. Proses pendaftaran peralihan hak milik atas tanah karena pewarisanyang berasal dari tanah ganggam bauntuak adalah sama dengan peralihan hak milik karena pewarisan lainnya, yaitu sesuai dengan Pasal 42 PP No. 24 Tahun 1997 tentang Pendaftaran Tanah, dan secara khusus diatur dalam Pasal 111 PMNA/K-BPN Nomor 3 Tahun 1997 tentang ketentuan pelaksana PP No. 24 tahun 1997.

\section{BIBLIOGRAFI}

Anwar, Chairul. 1997. Hukum Adat Indonesia, Meninjau Hukum Adat Minangkabau. Jakarta: PT Rineka Cipta.

Abna, Bachtiar dan Rajo Sulaiman. 2007. Pengelolaan Tanah Negara dan Tanah Ulayat, Padang:Lembaga Kerapatan Adat Alam Minangkabau (LKAAM) Sumatera Barat.

Ali, Zainuddin. 2009. Metode Penelitian Hukum. Jakarta: Sinar Grafika.

Mahyuddin, Suardi. 2009. Dinamika Sistem Hukum Adat Minangkabau dalam Yurisprudensi Mahkamah Agung. Jakarta: PT.Candi Cipta Paramuda

M.S, Amir. 2011. Pewarisan Harato Pusako Tinggi dan Pencaharian Minangkabau. Cetakan Keempat, Jakarta: Citra Harta Prima.

Penghulu, Idrus Hakimy Dt. Rajo Penghulu. 1978. Rangkaian Mustika Adat Basandi Syarak Di Minangkabau. Bandung: CV Rosda

Sandra, Desi. 2015. Pendaftaran Tanah Ulayat Kaum Untuk Kepastian Hukum Hak Atas Tanah di Kota Bukittinggi. Tesis. Padang: Fakultas Hukum Universitas Andalas.

Simom, Mhd Dwi. 2017. Peralihan Hak Milik Atas Tanah Kaum Berdasarkan Pewarisan di Kota Payakumbuh. Tesis. Padang: Fakultas Hukum Universitas Andalas.

Sunggono, Bambang. 1997. Metodologi Penelitian Hukum. Jakarta: PT Grafindo Persada. 
Thalib, Sajuti. 1985. Hubungan Tanah Adat dengan Hukum Agraria. Jakarta: Bina Aksara.

Tuo, Nurullah Dt. Perpatih Nan. 1999. Tanah Ulayat Menurut Ajaran Adat Minangkabau. Yayasan Sako Batuah LKAAM Sumatera Barat. Padang: PT.Singgalang Press.

Warman, Kurnia. 2006. Ganggam Bauntuak Menjadi Hak Milik: Penyimpangan Konversi Hak Atas Tanah di Sumatra Barat. Padang: Andalas University Press. 2010. Hukum Agraria Dalam Masyarakat Majemuk, Dinamika Interaksi Hukum Adat dan Hukum Negara di Sumatera Barat. Jakarta: Van Vollenhoven Institute Leiden University, KITLV \& HuMa-Jakarta.
Warman, Kurnia. 1999. "Konversi Hak Atas Tanah Ganggam bauntuak Menurut UUPA Di Sumatera Barat". Jurnal: Sosiohumanika, Yogyakarta, 12(2): 239240.

Wahyudi. 2016. Kedudukan Ganggam Bauntuak Dalam Harta Pusaka Tinggi Sebagai Tanah Ulayat Kaum Di Minangkabau. Skripsi. Bukittinggi: Fakultas Hukum Universitas Muhammadiyah Sumatera Barat.

Yakub, Nurdin. 1989. Minangkabau Tanah Pusaka, Tambo Minangkabau Buku Kedua. Cetakan Pertama. Bukittinggi: Pustaka Indonesia. 